\title{
Procedure Generation for Algorithm Learning System using Comment Synthesis and LSTM
}

\author{
Akiyoshi Takahashi *, Hiromitsu Shiina ${ }^{\dagger}$, \\ Ryunosuke Ito ${ }^{*}$, Nobuyuki Kobayashi ${ }^{\S}$
}

\begin{abstract}
We have constructed a learning system by organizing procedures for learning program creation. However, manually creating procedures for learning systems requires a significant amount of time. In this study, in addition to automatically generating program procedures using natural language processing, we generate new program content and procedures by learning program code and comments through deep learning long short-term memory.

Keywords: Programming learning, Comment Generating, Summarization, Neural Machine Translation, Encoder-Decoder Translation Model
\end{abstract}

\section{Introduction}

Training the ability to utilize information is important for the progress of an information society. In school education, it is important to enrich information and communications technology (ICT) education at every stage. Preparation has already begun in elementary, middle, and high schools; for example, programming education in elementary schools will be compulsory by 2020 in Japan [1]. Considering programming education for university students and the connection to ICT education in elementary, middle, and high school, it is necessary to prepare content for programming education and study its support system. In particular, it is important in ICT education to operate programs directly on computers; however, learning computational thinking [2] is more important than learning programming grammars. Many studies on programming education have been done [3]. As a related study, there is research on programming education for beginners using operation logs $[4,5]$.

In computational thinking, we have discussion on the relationship between computational thinking and logical thinking. Relationship with language management is being debated [6]. Though, the purpose of this study is to aid in understanding the procedures for solving problems, we have constructed an algorithm learning system that rearranges algorithm procedures on a tablet PC [7]. This system is intended for students studying programming at the university level. It differs from learning programming language grammar

* Graduate Shcool of Informatics, Okayama Univerity of Science, Okayama, Japan

$\dagger$ Okayama Univerity of Science, Okayama, Japan

\# Advanced Information Design, Tokyo, Japan

$\S$ Sanyo Gakuen University, Okayama, Japan 
and aims to simplify learning algorithms. We have evaluated the use of this system by international students at Okayama University of Science in Japan. Creating many exercises requires time and effort on the part of the lecturer; therefore, a system for automatically generating these exercises is beneficial and necessary. As a related work in the field of software engineering research, there is research on the generation of nouns for programming comment generation [8]. However, it is not study on the generation of comments.

As the first step, a summarization technology $[9,10,11]$ of division, merging, and paraphrase processing is used for program code comments. Since procedures are similar to comments, both can be generated automatically. The development of a method using neural networks has led to the development of natural language translation and sentence generation. In particular, an encoder-decoder translation using long short-term memory (LSTM [12]) has been proposed, which improved the translation accuracy. As the second step, pairs comprising one line of program code and its comments are learned in the encoder-decoder translation model used for the translation of program code to comments. In addition, LSTM generates a comment for a new piece of program code. In this study, we used 53 programs written in the $C$ language used in first year university lectures in Japan. While learning the computational thinking, it is important to be able to summarize and disassemble the explanation of an algorithm. Although it is not necessary to understand variables in the first stage of learning, it is necessary to understand the programming language in the second stage. In particular, it is necessary to understand changes in variables. In addition, since information about the variables is insufficient from the program code originally used for learning, the flow relating to the program variables tends to be difficult to understand. Therefore, the comment generation process includes the added conversion of variable information of learning program code and variable names to generate comments by LSTM.

\section{Algorithm learning system}

Programming involves a number of procedures, such as declaring variables, inputting values, performing calculations, and outputting results. This programming procedure test involves converting programming into Japanese and dividing the procedures into several parts. There is text that rearranges the divided procedures in sequential order so that they match the flow of the programming. This text is utilized for understanding learning situations in lectures.

For example, we consider a foreign currency conversion problem that involves creating a program that takes an amount in yen as input and returns its conversion to US dollars, pounds, or euros as output. The procedure for solving this problem can be divided into sections, as shown in Figure 1(a). In this study, we have developed a system for testing the problem of rearranging this text, as shown in Figure 1(b). 


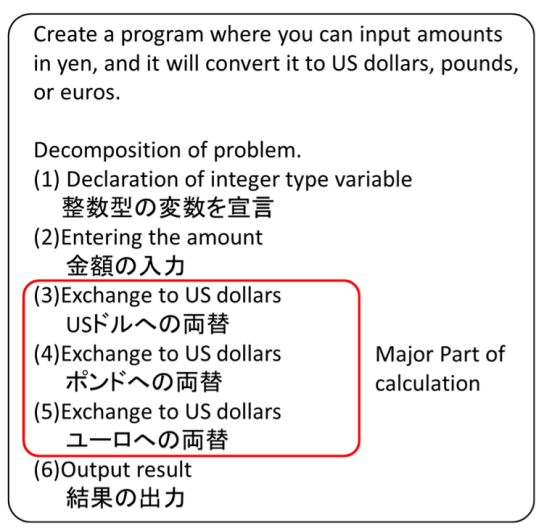

(a)Procedure learning test

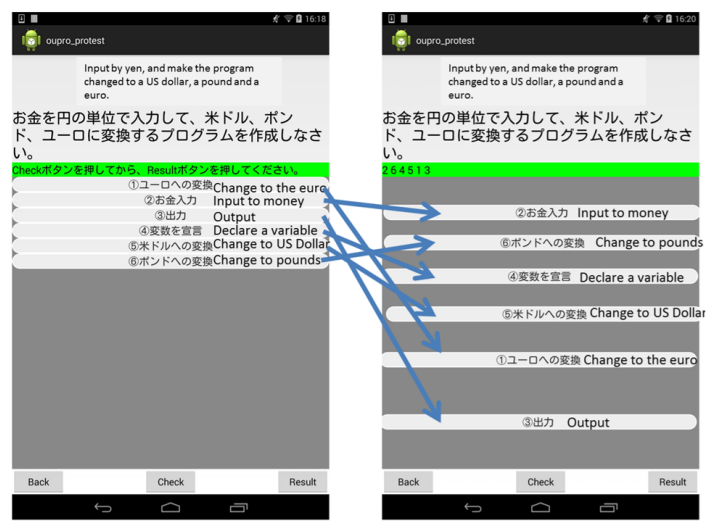

(b)Sorting procedure in Quiz

Figure 1: Procedure learning test and sorting procedures

\section{Procedure generation through comment synthesis using pro- gram structures}

In the algorithm learning system, procedures are generated by summarizing comments based on their vocabulary and degree of association with the lecture. material and the program structure, as shown in Figure 2.

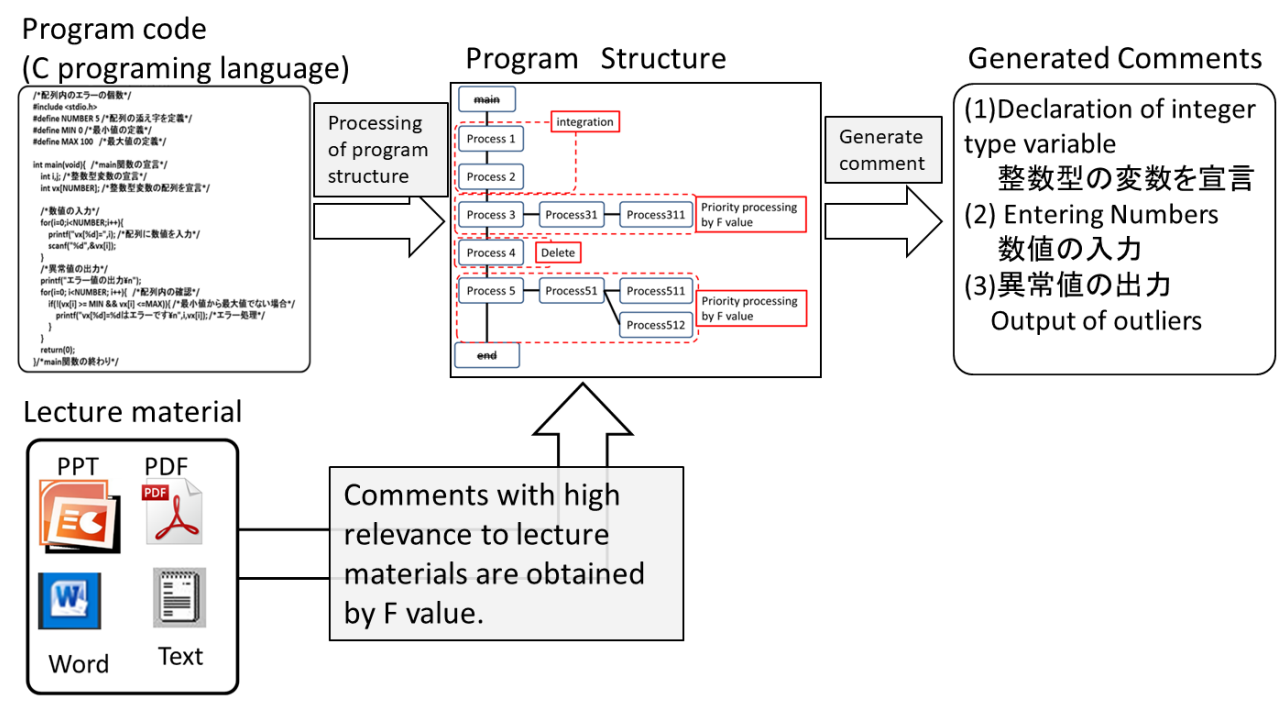

Figure 2: Outline of procedure generation system by comment Synthesis 


\subsection{Evaluation of comment priority}

Comment priority can be evaluated based on the following procedure. The overlap of important words between the comments in the program code and the lecture materials is given by the F-value, as shown in Figure 3.

(1) Obtain the term frequency inverse document frequency (TF-IDF) in the course material.

(2) Obtain the F-value for important words in the course material and program comments.

(3) Determine the comment evaluation value, which is the total F-value for the words included in the comment. This value selects comments with F-values over a certain threshold.

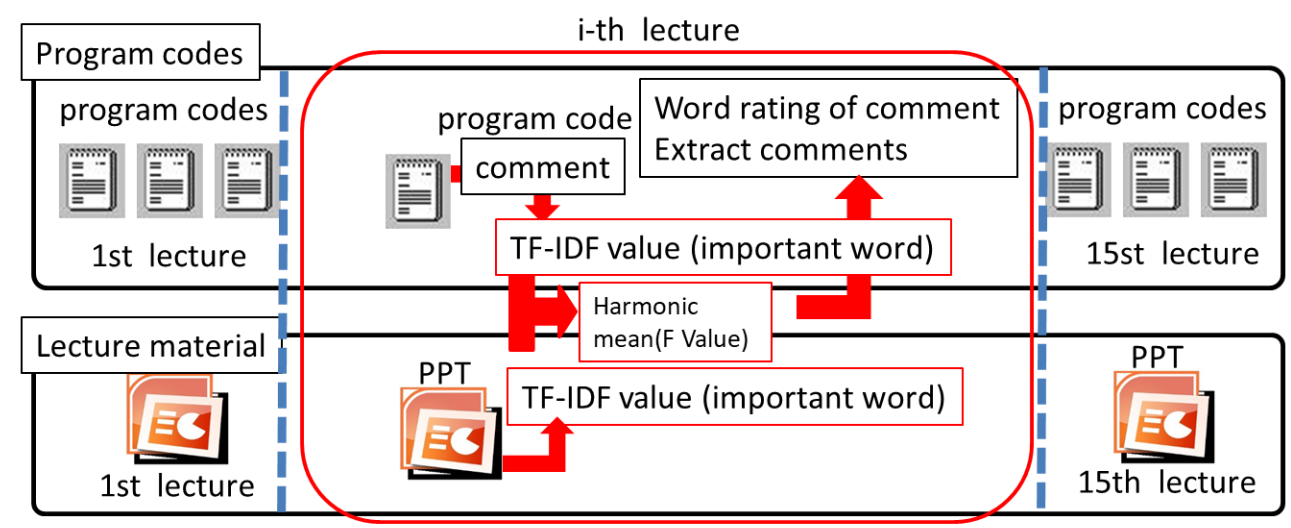

Figure 3: Important word shared by program comments and lecture material by F-value

\subsection{Procedure generation using program structure}

After deleting the comments, we merge the remaining comments using the merging conditions shown below. An example of the procedure generation is shown in Figure 4.

(1) For an unused function, the comments at its beginning and end are deleted.

(2) Parallel integration: comments at the same level in the program code in which the same noun is at the end of the statement are summarized as one statement.

(3) Deletion based on F-value: comments with small F-value s are deleted.

(4) F-value priority: lower layer comments are preserved for comments with large F-values. Figure 5 illustrates the comment synthesis results, using an example of source code. 


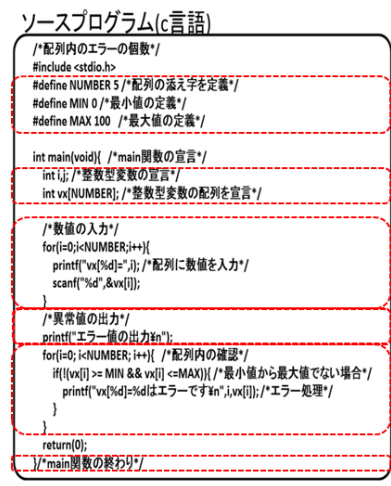

\begin{tabular}{|c|c|c|c|}
\hline Level & Comment & Generated Procedure & Process \\
\hline 1 & $\begin{array}{r}\text { 配列の添え字を定義 } \\
\text { Define number of array }\end{array}$ & \multirow{3}{*}{$\begin{array}{l}\text { 配列の添え字, 最小値, 最 } \\
\text { 大値の定義 } \\
\text { Definition of array subscript, } \\
\text { minimum value, maximum } \\
\text { value }\end{array}$} & \multirow{3}{*}{$\begin{array}{l}\text { 並列の統合 } \\
\text { Parallel } \\
\text { integration }\end{array}$} \\
\hline 1 & $\begin{array}{c}\text { 最小値の定義 } \\
\text { Definition of minimum value }\end{array}$ & & \\
\hline 1 & $\begin{array}{l}\text { 最大値の定義 } \\
\text { Definition of maximum val } \\
\text { ue }\end{array}$ & & \\
\hline 1 & $\begin{array}{l}\text { main関数の宣言 } \\
\text { Declaration of main } \\
\text { function }\end{array}$ & & 削除 \\
\hline 2 & $\begin{array}{l}\text { 整数型変数の宣言 } \\
\text { Declaration of integer } \\
\text { variable }\end{array}$ & \multirow{2}{*}{$\begin{array}{l}\text { 整数型配列変数の宣言 } \\
\text { Declaration of integer type } \\
\text { array variable }\end{array}$} & \multirow{2}{*}{$\begin{array}{l}\text { 並列の統合 } \\
\text { Parallel } \\
\text { integration }\end{array}$} \\
\hline 2 & $\begin{array}{l}\text { 整数型変数の配列を宣言 } \\
\text { Declare array of integer } \\
\text { variable }\end{array}$ & & \\
\hline 2 & $\begin{array}{l}\text { 数値の入カ } \\
\text { Entering Numbers }\end{array}$ & \multirow{2}{*}{$\begin{array}{l}\text { 配列に数值の入カ } \\
\text { Enter numerical value in array }\end{array}$} & \multirow{2}{*}{$\begin{array}{c}\text { F值の優先 } \\
\text { Selection by } \mathrm{Fv} \\
\text { alue }\end{array}$} \\
\hline 3 & $\begin{array}{l}\text { 配列に数値を入力 } \\
\text { Enter numeric value in array }\end{array}$ & & \\
\hline 2 & $\begin{array}{l}\text { 異常値の出力 } \\
\text { Output of outliers }\end{array}$ & & $\begin{array}{l}\mathrm{F} \text { 值によよる } \\
\text { 削除 } \\
\text { Delete by F } \\
\text { value }\end{array}$ \\
\hline 2 & $\begin{array}{c}\text { 配列内の確認 } \\
\text { Confirm in the array }\end{array}$ & $\begin{array}{l}\text { 配列内の確認 } \\
\text { Confirm in the array }\end{array}$ & \multirow{3}{*}{$\begin{array}{c}\text { F値の優先 } \\
\text { Selection by } F \\
\text { value }\end{array}$} \\
\hline 3 & $\begin{array}{l}\text { 最小値から最大値でない場合 } \\
\text { Case that is not the } \\
\text { minimum value to the } \\
\text { maximum value }\end{array}$ & $\begin{array}{l}\text { 最小値から最大値てない,場合 } \\
\text { Case that is not the minimum } \\
\text { value to the maximum value }\end{array}$ & \\
\hline 4 & $\begin{array}{c}\text { エラー処理 } \\
\text { Error handling }\end{array}$ & $\begin{array}{c}\text { エラ一処理 } \\
\text { Error handling }\end{array}$ & \\
\hline 1 & $\begin{array}{l}\text { main関数の終わり } \\
\text { End of main function }\end{array}$ & & 削除 Delete \\
\hline
\end{tabular}

Figure 4: Extraction of important comments by F-value

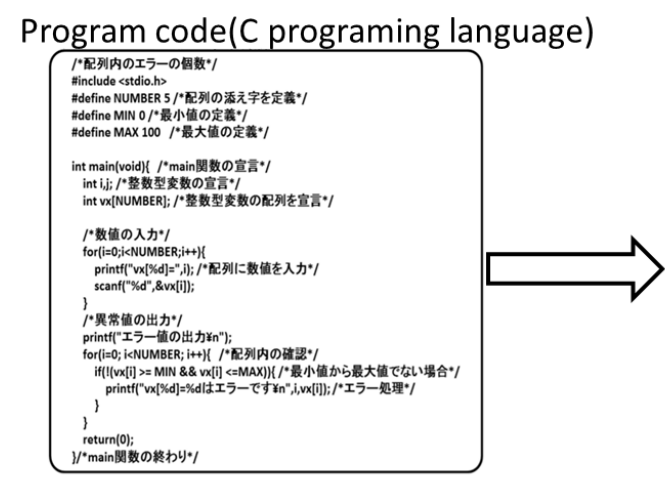

\section{Generated Comments}

(1) Define the size, minimum value, maximum value of the array.

配列の大きさ、最小値、最大値を定義する

(2) Declare the Main function.

Main関数を宣言する

(3) Declare an integer type array.

整数型の配列を宣言する。

(4) Enter numerical values in all subscripts of the array. 配列のすべての添え字内に数值を入力する

(5) Case that is not within the range from the minimum value to the maximum value

最小値から最大値内でない場合

(6) Error handling

エラ一処理

Figure 5: Comment synthesis results 


\subsection{Procedure evaluation based on comment synthesis using program struc- ture}

The deletion rate of the program comments extracted for evaluation was approximately $60 \%$. Additionally, nine participants studying the program participated in a questionnaire with a five-point rating system (ranging from 1 [bad] to 5 [good]) regarding the following two questions:

(1) Evaluation of procedure text

(2) Program understanding related to the procedure

The results of this questionnaire are shown in Table 1. In the text evaluation of the questionnaire, half or more of the participants evaluated it as ordinary text; however, when asked to evaluate their understanding of the content of the program based on this text, many participants awarded a rating of 2 , which is considerably low. We conjectured that the large amount of low ratings resulted from the fact that the procedure generation ended with an initial declaration of variables.

Table 1: Evaluation of generated procedure by F-value

\begin{tabular}{|l|c|c|c|c|c|}
\hline \multirow{2}{*}{ Questionnaire } & \multicolumn{5}{|c|}{ Evaluation(1-5) } \\
\cline { 2 - 6 } & 1 & 2 & 3 & 4 & 5 \\
\hline (1) Evaluation of procedure & $0 \%$ & $27 \%$ & $62 \%$ & $11 \%$ & $0 \%$ \\
\hline $\begin{array}{l}\text { (2) Program understanding } \\
\text { related to the procedure }\end{array}$ & $0 \%$ & $46 \%$ & $43 \%$ & $9 \%$ & $2 \%$ \\
\hline
\end{tabular}

\section{Procedure generation with LSTM}

In cases where the program code contains comments, it is possible to generate procedures using the summary technology described in the previous section; however, not all program code has attached comments. Therefore, it is necessary to learn to generate comments on program code lacking comments from the programs with attached comments. Previous studies considered using an encoder-decoder translation model $[13,14]$ that use deep learning LSTM to translate. In addition, sentnce summarization by neural network is proposed by Rush [15].

In this study, we use this translation model to translate the program code into comments and attempt to generate comments and procedures. There are two steps to the process. The first is the generation of procedures one line at a time from the program code. The second is the generation of procedures related to program block units across multiple lines, such as if and while constructs. Procedures pertaining to the program code are generated by learning using the encoder-decoder translation model via LSTM on the program code and comment pair discussed in the previous section. In addition, procedures are generated for programs that do not have attached comments. To generate procedures using the encoder-decoder translation model, it is necessary to perform preprocessing on the learned data, define the encoder-decoder translation model, and learn the data. The general flow of the procedure generation model is shown in Figure 6. 


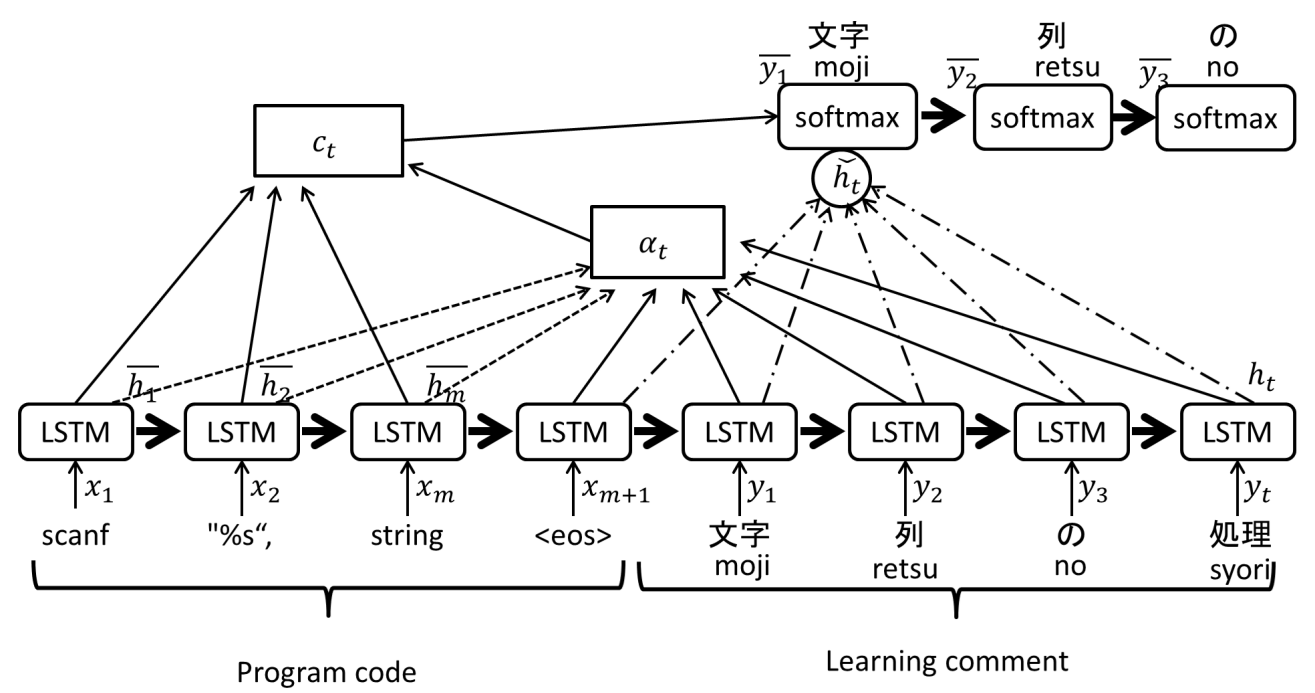

Figure 6: Encoder-decoder translation model for neural machine translation from comments to procedure

\subsection{Preprocessing of learning data of program code and comments.}

To learn using the encoder-decoder translation model, it is necessary to separate the program source code from the comments. The LSTM model takes a sequence of program source code tokens as input and a word sequence of comments as $X=x_{1}, \ldots x_{i}, \ldots$. The token is converted to the token ID number, and similarly, the word is converted to the word ID number.

\subsection{Encoder-Decoder translation model using LSTM}

With LSTM blocks, a sigmoid layer is used, and the information that should and should not be considered is set to 0 and 1, respectively. Furthermore, the error from the data saved in advance for the translation pair is lost, and the loss for each LSTM block is accumulated. Finally, the parameters are learned by performing an error back propagation method on the loss.

(1) With encoder-decoder translation model $\alpha_{t}$, a normalization of the degree of similarity is performed for output ht in relation to $y_{t}$, and $\bar{h}_{i}$ on the encoder side. $c_{t}$ creates context vectors using the degree of similarity obtained with $\alpha_{t}$ and $\bar{h}_{t}$.

(2) In the LSTM output using the encoder-decoder translation model, $c_{t}$ and $\bar{h}_{t}$ are linked to create a vector, and weight is applied with a linear operator. By applying the activation function tanh to this, the intermediate layer $\breve{h}_{i}$ is output in relation to $y_{t}$. Finally, a weight is applied with a linear operator with respect to $\breve{h}_{i}$, and $\bar{y}_{t}$ is output with the softmax function.

\subsection{Data learning with a source code comments pair}

Learning is performed multiple times using the defined procedure generation model. LSTM is used for learning data, and screening occurs using the sigmoid layer to select whether input $x_{i}$ is required. Furthermore, the loss with the accuracy data that was saved in advance is obtained. The accumulated loss is obtained and the parameter is retained after performing 
an error back propagation method. The retained parameter is passed to the next model and learning occurs. Additionally, in the LSTM implementations and algorithms, there are models that generate procedures learned from the tokens and comments for each line and block of program code.

\subsection{Procedure generation and evaluation}

Examples of generating 20,100, and 500 learning times for the model learning by line and by block are shown in Figures 7 and 8, respectively.

(1) Evaluation of procedures generated by line For procedures generated by line, learning in terms of comments was not achieved at all after several learning attempts; however, nearly 20 learning attempts resulted in the desired procedures. After 100 learning attempts, procedures were properly generated in relation to approximately $80 \%$ of all of the program code. After 500 learning attempts, the procedure generation converged, but in the case of other procedures repeatedly generated in an unstable way, there was a decrease in the number of procedures generated with a correct meaning in Japanese.

(2) Evaluation of procedures generated by block

In contrast to procedures generated by line, procedures generated by block were generated after a smaller number of learning attempts. Those with simple and short blocks or a large portion of code similar to the learning data were able to generate good code. In contrast, the procedure generation text that failed either included many words that were not registered as data or lacked distinct terms. The results were also dependent on the volume of the learning data.

\subsection{Rating using a questionnaire on procedure generation}

The results of the manually conducted questionnaire are shown in Tables 2 and 3, and the following observations can be made based on the ratings.

(1) When rating by line, the participants often understood the meaning of the procedures. The procedures were considered easy to understand regardless of the flow of the program.

(2) There was a significant difference in results depending on whether all blocks had either different or nearly identical learning data. This accounts for the clear differences in ratings indicating whether the procedures were understandable. However, there was a poor result because the meaning of the important sections of the processing was not understood. 


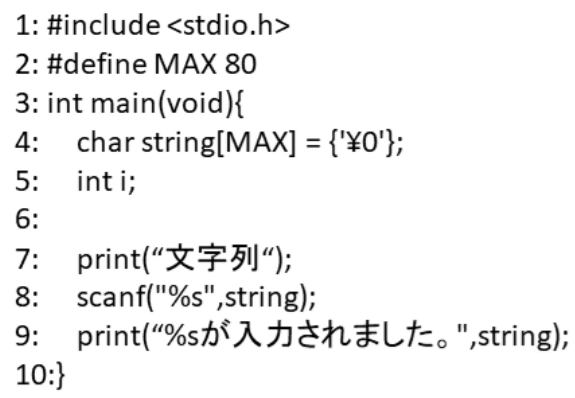

\section{(a)Test program}

\section{1: Include header}

ヘッダーの読み込み

2: Define the maximum value

最大値の定義づけ

3: Declare the integer type array 整数型の配列を宣言

4: For input string

入力文字列用

5: Declare the integer type variable

\section{整数型変数の宣言}

6:

7: Display texts prompting input processing 入力処理を促す文章を表示

8:Make an integer

整数をする

9: Display input character string 入力された文字列を表示

10:

(b)20 learning times

\author{
1: Include header \\ ヘッダーの読み込み \\ 2: Define the maximum value \\ 最大值を定義づけ \\ 3: Declaration of main function \\ main関数の宣言 \\ 4: For input string \\ 入力文字列用 \\ 5: Declare an integer type variable \\ 整数型変数を宣言 \\ 6: \\ 7: Display texts prompting input processing \\ 入力処理を促す文章を表示 \\ 8: Enter character string \\ 文字列を入力 \\ 9: Display the input character string \\ 入力された文字列を表示 \\ 10:
}

\section{(c)100 learning times}

\section{1: Include header ヘッダーの読み込み}

2: Define the maximum value 最大值を定義づける

3: Declaration of main function main関数の宣言

4: For input string 入力文字列用

5: Declaration of integer variable 整数型変数の宣言

7: Display sentence urging input processing 入力処理を促す文章を表示

8: Enter character string 文字列を入力

9: Display text to prompt input processing 入力処理を促す文章を表示

10:

(d)500 learning times

Figure 7: Example of procedure generations 


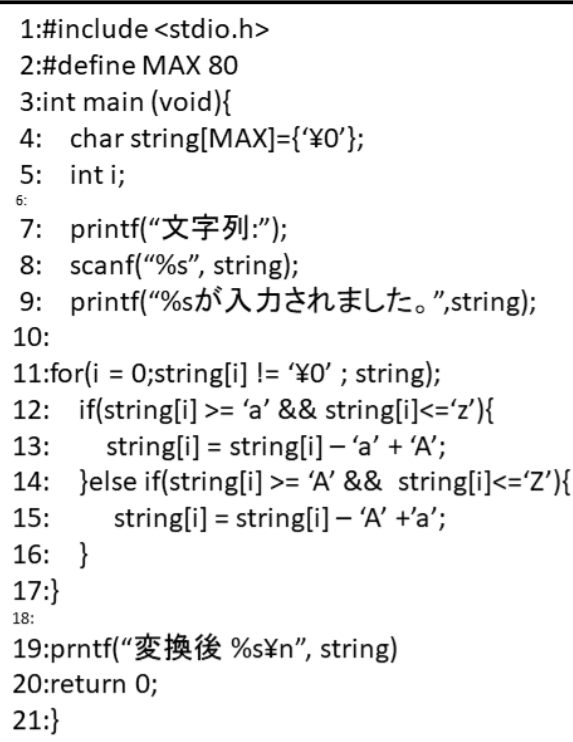

(a)Test program
Lines 1 to 5: none

Lines 7 to 9: input processing 入力処理

Lines 11 to 17: Output of standard weight

標準体重の出力

Lines 19 to 21: output the result 結果の出力

\section{(b)20 learning times}

\section{Lines 1 to 5 : none}

Lines 7 to 9: input processing 入力処理

Lines 11 to 17: Output of outliers

異常値の出力

Lines 19 to 21: output the result 結果の出カ

(c)100 learning times

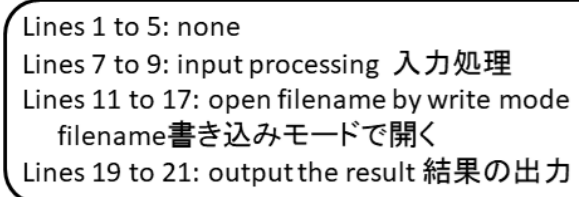

(d)500 learning times

Figure 8: Procedure generation for each block of source code by encoder-decoder translation model

Table 2: Evaluation of generated procedure by line

\begin{tabular}{|c|l|c|c|c|c|c|c|}
\hline \multirow{2}{*}{$\begin{array}{c}\text { Line } \\
\text { number }\end{array}$} & Generated procedure & \multicolumn{5}{|c|}{ Evaluation(1-6) } \\
\cline { 4 - 8 } & & 1 & 2 & 3 & 4 & 5 & 6 \\
\hline 1 & $\begin{array}{l}\text { Include standard input output file } \\
\text { 標準入カファイルの読込 }\end{array}$ & 0 & 0 & 0 & 0 & 0 & 5 \\
\hline 2 & $\begin{array}{l}\text { Definition of maximum value } \\
\text { 最大值の定義 }\end{array}$ & 0 & 0 & 0 & 0 & 0 & 5 \\
\hline 3 & $\begin{array}{l}\text { Declaration of main } \\
\text { main の宣言 }\end{array}$ & 0 & 0 & 0 & 0 & 0 & 5 \\
\hline 4 & $\begin{array}{l}\text { For input string } \\
\text { 入力文字列用 }\end{array}$ & 0 & 3 & 2 & 0 & 1 \\
\hline 6 & $\begin{array}{l}\text { Declare the integer type variable } \\
\text { 整数型変数を宣言 }\end{array}$ & 0 & 0 & 0 & 0 & 0 & 5 \\
\hline 7 & $\begin{array}{l}\text { Display text prompting } \\
\text { input processing } \\
\text { 入力処理を促す文章を表示 }\end{array}$ & 0 & 0 & 0 & 0 & 0 & 5 \\
\hline 8 & $\begin{array}{l}\text { Enter a character string } \\
\text { 文字列を入力 }\end{array}$ & 0 & 0 & 0 & 0 & 0 & 5 \\
\hline 9 & $\begin{array}{l}\text { Display the input character string } \\
\text { 入力された文字列を表示 }\end{array}$ & 0 & 0 & 0 & 0 & 0 & 5 \\
\hline
\end{tabular}


Table 3: Evaluation of generated procedure by each block

\begin{tabular}{|c|c|c|c|c|c|c|c|}
\hline \multirow{2}{*}{$\begin{array}{l}\text { Line } \\
\text { number }\end{array}$} & \multirow{2}{*}{ Generated procedure } & \multicolumn{6}{|c|}{ Evaluation(1-6) } \\
\hline & & 1 & 2 & 3 & 4 & 5 & 6 \\
\hline $1-5$ & none & 1 & 0 & 0 & 1 & 0 & 3 \\
\hline $7-9$ & $\begin{array}{l}\text { input processing } \\
\text { 入力処理 }\end{array}$ & 0 & 0 & 0 & 0 & 0 & 5 \\
\hline $11-17$ & $\begin{array}{l}\text { Output of outliers } \\
\text { 異常值の出力 }\end{array}$ & 0 & 5 & 0 & 0 & 0 & 0 \\
\hline $19-21$ & $\begin{array}{l}\text { Output of result } \\
\text { 結果の出力 }\end{array}$ & 0 & 0 & 3 & 2 & 0 & 0 \\
\hline
\end{tabular}

\section{Procedure generation with addition of variable information}

In computational thinking learning, it is necessary to be able to summarize and disassemble the explanation of an algorithm. Although it is not necessary to understand variables in the first stage of learning, it is necessary to understand the programming language in the second stage. In particular, it is necessary to know about variable changes. In addition, since information about the variables is insufficient with only the program code originally used for learning, the flow related to the program variables tends to be difficult to understand. Therefore, the procedure generation process is introduced in added conversion of the variable information of the learning program code and variable names to generate procedures by LSTM. The process of generating procedures including variables is explained separately for the conversion of learning data and the conversion of test data.

(1) Process learning data variables.

(1-1) Convert the learning program variables into temporary variable names, such as string1 for $\mathrm{x}($ string $1 \rightarrow \mathrm{x})$ and $\mathrm{i}$ for $\mathrm{x}(\mathrm{i} \rightarrow \mathrm{x})$.

(1-2) Convert the learning data variable to a temporary variable name (x).

(1-3) Learn data that processes variable information repeatedly.

(2) Process test data variables.

(2-1) Obtain the variable information of each line from the test data to apply it to procedure generation.

(2-2) Convert the test data variable to a temporary variable name.

(2-3) Generate procedures from the test data whose variables are returned using LSTM.

(2-4) Restore the original variable name from the temporary name in the generated procedure. 


\begin{tabular}{|c|c|c|c|c|c|c|c|c|c|c|c|c|c|c|c|}
\hline \multirow{2}{*}{\multicolumn{2}{|c|}{ Test program }} & \multirow{3}{*}{$\begin{array}{l}\text { Comment generated } \\
\text { by LSTM } \\
\text { Start of main function } \\
\text { main 関数の宣音 }\end{array}$} & \multirow{3}{*}{$\begin{array}{l}\text { Comment generation variable } \\
\text { information } \\
\text { Start of main function } \\
\text { main 閔数の宣言 }\end{array}$} & \multicolumn{6}{|c|}{ Procedure Evaluation } & \multicolumn{6}{|c|}{ Variable Evaluation } \\
\hline & & & & 1 & 2 & 3 & 4 & & 6 & 1 & 2 & 3 & 4 & 5 & 6 \\
\hline 4 & int main(void) \{ & & & 0 & 0 & 0 & 0 & 0 & 5 & 0 & 0 & 0 & 0 & 0 & 5 \\
\hline 5 & int $\mathrm{i}, \mathrm{j}$ & $\begin{array}{l}\text { Declaration of integer type }(\mathrm{x}),(\mathrm{x}) \\
\text { 整数型恝数 }(\mathrm{x})(\mathrm{x}) \text { の宣言 }\end{array}$ & $\begin{array}{l}\text { Declaration of integer type (i), (j) } \\
\text { 整数型㚆数 (1)(0) の嘗尚 }\end{array}$ & 0 & 0 & 0 & 0 & 0 & 5 & 0 & 0 & 0 & 0 & 0 & 5 \\
\hline 6 & float $\max$; & $\begin{array}{l}\text { Declaration of floating point(x) } \\
\text { 浮䣦小数点型変数 (x)の宣吉 }\end{array}$ & $\begin{array}{l}\text { Declaration of floating point(max) } \\
\text { 浮跔小数点型変数 }(\max ) \text { の宣目 }\end{array}$ & 0 & 0 & 0 & 0 & 0 & 5 & 0 & 0 & 0 & 0 & 0 & 5 \\
\hline 7 & float vx[NUMBER]; & $\begin{array}{l}\text { Declaration of floating point(x) } \\
\text { 浮煙小数点型恝数 (x)の宣吉 }\end{array}$ & $\begin{array}{l}\text { Declaration of floating point(vx) } \\
\text { 浮㖶小数点型変数 }(\mathrm{vx}) \text { の宣吉 }\end{array}$ & 0 & 0 & 0 & 0 & 1 & 4 & 0 & 0 & 0 & 0 & 3 & 2 \\
\hline 8 & for $(\mathrm{i}=0 ; \mathrm{i}<\mathrm{NUMBER} ; \mathrm{i}++)\{$ & 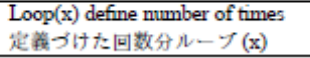 & $\begin{array}{l}\text { Loop(i) define number of times } \\
\text { 走教つけた回数分ループ(i) }\end{array}$ & 0 & 0 & 0 & 0 & 1 & 4 & 0 & 0 & 0 & 0 & 2 & 3 \\
\hline 9 & printf("vx[\%d]=", i); & $\begin{array}{l}\text { Display result } \\
\text { 計算結果の表示 }\end{array}$ & $\begin{array}{l}\text { Display result } \\
\text { 林算結果の表示 }\end{array}$ & 0 & 0 & 0 & 0 & 1 & 4 & 0 & 0 & 0 & 0 & 3 & 2 \\
\hline 10 & $\operatorname{scanf}\left(" \% f^{\prime}\right.$, \&vx[i]); & $\begin{array}{l}\text { Enter floating point }(\mathrm{x})(\mathrm{x}) \\
\text { 浮怔小数点の入力を行 } 5(\mathrm{x})(\mathrm{x})\end{array}$ & 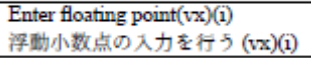 & 0 & 0 & 0 & 0 & 2 & 3 & 0 & 0 & 1 & 0 & 1 & 3 \\
\hline 11 & \} & & & & & & & & & & & & & & \\
\hline 13 & $\max =v x[0]$ & $\begin{array}{l}\text { Enter the initial value }(\mathrm{x})(\mathrm{x}) \\
(\mathrm{x}) \text { を初期值 }(\mathrm{x})(\mathrm{x}) \text { を入力 } \\
\text { ま行与 }\end{array}$ & 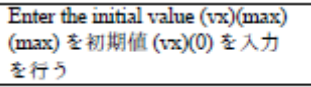 & 1 & 0 & 1 & 1 & 2 & 0 & 1 & 2 & 0 & 2 & 0 & 0 \\
\hline 14 & for $(i=0 ; i<$ NUMBER; $i+-)\{$ & $\begin{array}{l}\text { Loop(x) define number of times } \\
\text { 走義つけた回数分ルーフフ (x) }\end{array}$ & 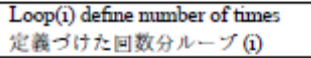 & 0 & 0 & 0 & 0 & 1 & 4 & 0 & 0 & 0 & 0 & 1 & 4 \\
\hline 15 & if $(\max <\mathrm{vx}[\mathrm{i}])\{$ & $\begin{array}{l}\text { (x) is smaller } \\
\text { (x)の方が小さい }\end{array}$ & $\begin{array}{l}\text { (x) is smaller } \\
(\max ) の \text { のが小ざ }\end{array}$ & 1 & 0 & 2 & 2 & 0 & 0 & 1 & 2 & 0 & 2 & 0 & 0 \\
\hline 16 & $\max =v x[1]$ & 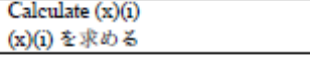 & $\begin{array}{l}\text { Calculate }(\max )(\mathrm{i}) \\
(\max )(\mathrm{i}) \text { え求める }\end{array}$ & 2 & 1 & 0 & 1 & 1 & 0 & 2 & 2 & 1 & 0 & 0 & 0 \\
\hline 17 & \} & & & & & & & & & & & & & & \\
\hline 18 & & & & & & & & & & & & & & & \\
\hline 19 & printf("最大傎 = \% f , max); & $\begin{array}{l}\text { Display maimum value }(\mathrm{x}) \\
\text { 最大值 }(\mathrm{x}) \text { 老表 }\end{array}$ & $\begin{array}{l}\text { Display maimum value(max) } \\
\text { 最大值 (max) を表示 }\end{array}$ & 0 & 0 & 0 & 0 & 0 & 5 & 0 & 0 & 0 & 0 & 0 & 5 \\
\hline 21 & retum $(0)$; & $\begin{array}{l}\text { End funciton } \\
\text { 閔数の䊀了 }\end{array}$ & $\begin{array}{l}\text { End funciton } \\
\text { 闌影の終了 }\end{array}$ & 0 & 0 & 0 & 0 & 1 & 4 & 0 & 0 & 0 & 0 & 1 & 4 \\
\hline 22 & \} & & & & & & & & & & & & & & \\
\hline
\end{tabular}

Figure 9: Procedure generation by LSTM and procedure conversion after variable name processing

Figure 9 shows the procedure generation by LSTM, the comment conversion after variable name processing, correctness of generated procedure and correctness of addition of variable information by five students. We evaluated each line of the generated procedure. Two questionnaires were administered to five participants in the fourth grade, each questionnaire evaluating the validity of the program and the variable information. The evaluations of the procedure generation and variable information had high ratings, and the accuracy of complementing the variable information was also high.

\section{Conclusion and future work}

In this study, we generated procedures to simplify understanding algorithms. We used source code and comments as pairs of learning data. It is possible to generate procedures from a source code when the purpose of the program is limited, such as in the case of course material. Structure information is not using in learning data pairs. Using parse data as structure information is an remarkable improvement for generating procedures for blocking source code. In future research, we would like to extend the translation model beyond source codes and generate LSTM comments in a merged form, from both textbook and course information. 


\section{References}

[1] Ministry of Education, Culture, Sports, Science and Technology, "Elementary school programming education guide (2nd edition)," 2018. [Online] Available: http:/ /www.mext.go.jp/a_menu/shotou/zyouhou/detail/1403162.htm, [Accessed Nov. 15, 2018] (in Japanse).

[2] Ministry of Education, Culture, Sports, Science and Technology. "How to programming education at elementary school level (Summary of discussion)." 2016. [Online] Available: http://www.mext.go.jp/b_menu/shingi/chousa/shotou/122/attach/ 1372525.htm , [Accessed Nov. 15, 2018] (In Japanese).

[3] H. Kanamori, T. Tomoto and T. Akakura, "Development of a Computer Programming Learning Support System Based on Reading Computer Program," Human Interface and the Management of Information. Information and Interaction for Learning, Culture, Collaboration and Business (HIMI) 2013, pp. 63-69, Springer, 2013. DOI:10.1007/978-3-642-39226-9_8

[4] K. Okimoto, S. Matsumoto, S. Yamagishi and T. Kashima, "Developing a source code reading tutorial system and analyzing its learning log data with multiple classification analysis," Artificial Life and Robotics, Vol 22, No. 7, pp. 227-237, 2017. DOI:10.1007/s10015-017-0357-2

[5] S. Matsumoto, K. Okimoto, T. Kashima and S. Yamagishi, "Automatic Generation of C Source Code for Novice Programming Education, Human-Computer Interaction," Theory, Design, Development and Practice 2016, pp. 65-76, 2016. DOI:10.1007/9783-319-39510-4_7

[6] M. Oba, K. Ito, and A. Shimogoori, "Analysis of Correlation between Programming Skills and Technical Writing Skills," IPSJ SIG Technical Report, Vol 2015-IFAT-118 No. 2, pp. 1-4, 2015.

[7] K. Sakane, N. Kobayashi, H. Shiina and F. Kitagawa, "Kanji Learning and Programming Support System which conjoined with a Lecture," IEICE Technical Report, ET2014-86, Vol. 114, No. 513, pp. 7-12, 2015.

[8] F. Tetsuya, Y. Hayase and K. Inoue, "Generating Descriptions of Nouns in Software from Program Comments," IEICE-110, no. 169, pp. 65-69, 2010.

[9] I.Mani and E. Bloedorn, "Multi-document summarizzation by graph search and matching," In Proc. 14th National Conferenece on Artificial Intelligence, pp. 622-628 1997.

[10] D. Marcu, "Improving summarization through rhetorical parsing tuning," In Proc. 6th Workshop on Very Large Corpora, pp.206-215, 1998.

[11] I. Mani. Automatic Summarization, John Benjamins Pub Co, 2001. DOI:10.1075/nlp.3

[12] K. Greff, et al., "LSTM: A Search Space Odyssey," IEEE Transactions on Neural Networks and Learning Systems, Vol. 28, Issue10, pp. 2222-2232, 2017. 
[13] I. Sutskever, O. Vinyals and Q. Le, "Sequence to Sequence Learning with Neural Networks," Advances in Neural Information Processing Systems 27 (NIPS 2014), pp. 3104-3112, 2014.

[14] M. Luong, H. Pham and D. Manning, "Effective Approaches to Attention-based Neural Machine Translation," arXiv preprint arXiv:1508.04025v5, 2015.

[15] A. Rush, S. Chopra and C. Weston, "A Neural Attention Model for Sentence Summarization," In Proc. EMNLP 2015: Conference on Empirical Methods in Natural Language Processing, pp. 379-389, 2015. 